Article

\title{
Learning Effect in a Multilingual Web-Based Argumentative Writing Instruction Model, Called ECM, on Metacognition, Rhetorical Moves, and Self-Efficacy for Scientific Purposes
}

\author{
Rosario Arroyo González (D), Eric Fernández-Lancho *(i) and Juan Antonio Maldonado Jurado \\ Department of Didactics and School Organization, University of Granada, 18011 Granada, Spain; \\ rarroyo@ugr.es (R.A.G.); jamaldo@ugr.es (J.A.M.J.) \\ * Correspondence: ericfernandez@correo.ugr.es
}

\section{check for}

updates

Citation: Arroyo González, R.; Fernández-Lancho, E.; Maldonado Jurado, J.A. Learning Effect in a Multilingual Web-Based

Argumentative Writing Instruction Model, Called ECM, on Metacognition, Rhetorical Moves, and Self-Efficacy for Scientific

Purposes. Mathematics 2021, 9, 2119.

https://doi.org/10.3390/math9172119

Academic Editor: Joaquín Paredes

Received: 31 July 2021

Accepted: 27 August 2021

Published: 1 September 2021

Publisher's Note: MDPI stays neutral with regard to jurisdictional claims in published maps and institutional affiliations.

Copyright: (c) 2021 by the authors. Licensee MDPI, Basel, Switzerland. This article is an open access article distributed under the terms and conditions of the Creative Commons Attribution (CC BY) license (https:// creativecommons.org/licenses/by/ $4.0 /)$.
Abstract: The purpose of this study is to assess the learning effect of a multilingual web-based argumentative writing instruction model called the Ensayo Científico Multilingüe (ECM, Multilingual Scientific Essay) adapting the didactic model called Genre-based Writing Instruction (GBWI) in an experiment conducted over three months. For this purpose, a quasi-experimental research model was applied to 150 students in the experimental group and 150 in the control group, with two measurements, pre and post-test, for three dependent variables: (a) writing metacognition and its dimensions; (b) written argumentative self-efficacy; and (c) rhetorical moves and steps of an argumentative essay. The latter variable was measured by the content analysis method. Variables (a) and (b) were both measured with instruments validated in a population of 518 university students using structural equations. The findings demonstrate the positive effect of the ECM, which combines WBWI and GBWI in argumentative written learning in the students' mother tongue in all variables measured, applying statistics such as the Shapiro-Wilk statistic, parametric contrast, and the Wilcoxon signed-rank test. In relation to the findings, with respect to the evaluated variables, it was discovered, specifically, that the rhetorical steps in which the students showed a significant improvement were innovations, quotes/research, definitions of concepts, refutations, definitive reasons, and bibliographical references. Likewise, the rhetorical steps that did not present significant differences following the application of the ECM were discovered, and they were: reason summary, formulation of premise, and reasons for. Furthermore, it can be stated that for the ECM there was an increase, above all, in awareness of the following metacognitive dimensions: (a) writing selfregulation; (b) writing planning; and (c) writing revision, as well as argumentative self-efficacy. The novelties of this research with respect to the precedents reside in that it offers valid and concrete results on the effect of a multilingual web design integrated into a well-defined didactic model of argumentative writing on writing metacognition and its dimensions, argumentative structuring and its rhetorical steps, and argumentative self-efficacy. The related studies consider only some of these variables, but not all of them together or their complexity. These results have allowed us to establish specific didactic-technological proposals for improving the ECM that are transferable to didactic designs to guide written argumentation at higher academic levels using multilingual web technologies and integrating the metacognitive, behavioral, and motivational dimensions of writing.

Keywords: technologies for writing communication; didactics of written language; argumentative self-efficacy; rhetorical moves; writing metacognition; university; multilingual scientific essay; genrebased writing instruction

\section{Introduction}

Today, the teaching of academic writing at universities, where a written argument constitutes an essential scientific development skill [1-3], is contextualized in technologies called "web-based instruction" [4] to respond to the multicultural demands of the 21st Century [5]. 
"Web-based instruction is conveyed to participants via the Internet and represents an alternative method that can be used with different target groups, for example, students and professionals." ([6] p. 88). As regards writing training, attention is drawn to the importance of web-based instruction for scientific argumentative writing, which means designing a didactic interaction that promotes both metacognitive learning about writing $[7,8]$ and adequate organization or structuring of the argumentative text [9], all the while activating some factor, particularly self-efficacy, that motivates the student towards scientific writing tasks.

Looking closer at these ideas, despite the insistence on web-based instruction allowing for degree students to more effectively improve their writing in an autonomous and collaborative manner $[10,11]$, there is an appreciation of a lack of written research, at the university level, using mathematics, that enquires into the effectiveness of web-based writing instruction at offering a broad multilingual space for guiding learning about argumentative essay writing and assessing different dimensions, such as metacognition, self-efficacy, and rethorical moves. In this study, the assessment is focused on "a student's achievements in order to establish whether they have reached a particular standard" [12] in the dimensions measured. This study applies statistics such as: (a) Cronbach's alpha coefficient to verify the internal consistency of the instruments; (b) McDonald's omega coefficient to verify reliability; (c) a t-test; (d) exploratory factor analysis (EFA); (e) confirmatory factor analysis (CFA); (f) the Shapiro-Wilk statistic; (g) parametric contrast; (h) Kappa index and (i) the Wilcoxon signed-rank test [13-16].

Moreover, a study by Teng et al. [17] confirms, with structural equations, the interdependence between the writing metacognition, the writing motivation, and the writing performance of students at higher levels. More specifically, a study conducted by Arroyo et al. [18], including correlation, linear regression, and structural equations, demonstrates the predictive power of structural rhetorical moves on the writing metacognition expressed in argumentative essays written by university students. Thus, the findings suggest a correlation between writing metacognition and writing self-efficacy in line with other studies [19-21]. Furthermore, they serve as the basis for the design of writing programs at the university level focused on the proper structuring of the text, promoting writing metacognition and argumentative self-efficacy. This study therefore aims to respond to the following questions:

Does web-based writing instruction in different languages have an effect on the way students organize their argumentative essays in their native language? Does multilingual web-based writing instruction affect the inclusion of the different rhetorical moves and steps of the argumentative essay differently?

Does web-based writing instruction have an effect on the writing metacognition of students, measured with validated instruments in the context of learning and in their native tongue? Does this metacognitive writing improvement affect the cognitive and sociocultural dimensions of writing differently?

Does web-based writing instruction have an effect on the written argumentative selfefficacy of students, measured with validated instruments in the context of learning and in their native tongue?

The state of research in relation to the proposed variables is established in order to respond to these questions.

The main innovations that the findings of this research bring with respect to previous similar investigations are the following:

In the first place, the use of statistics will enable the assessment of writing metacognition and its dimensions, argumentative self-efficacy, and the rhetorical steps of argumentative writing in a multilingual WBWI integrated within the GBWI didactic model in a course called ECM. Previous studies that apply the WBWI model integrated into GBWI use monolingual [22-24] or bilingual [25,26] environments. Furthermore, in these studies, either only the rhetorical movements $[24,25]$ are evaluated or the relevance, format, reliability, level, timeliness [26], and usability [23] of the software are described. In a study [27], 
writing metacognition, argumentative self-efficacy, and organization of argumentative writing are evaluated; however, the number of participants is low and the dimensions of writing metacognition and the argumentative rhetorical steps are not considered. The same occurs in other study [22] in relation to the mentioned variables, although in this case a multilingual context is used. This is a pilot study evaluating the effects of the ECM in the mother tongue (L1) and the first foreign language (L2).

Second, in relation to the results concerning the variables evaluated, those rhetorical steps in which the students showed a significant improvement were discovered. In the same way, the rhetorical steps that did not present significant differences following the application of the ECM were established. In addition, the metacognitive dimensions in which the students showed outstanding improvements were determined, as well as those that presented fewer differences. All of these findings are unprecedented in the results of similar studies.

Another novelty unprecedented is the design and validation of instruments that measure the dimensions of writing metacognition and argumentative self-efficacy in the context of the research itself, in addition to the application of the content analysis method to identify the rhetorical steps of argumentative essays written by university students.

Finally, this research process allowed us to establish specific improvements in the proposed didactic-technological model that are transferable to other researchers interested in teaching multilingual argumentative written communication of a scientific nature at higher levels.

\subsection{Assessing the Organization of an Argumentative Essay}

Interest in the way students organize their argumentative essays in university contexts appears in studies that assess the rhetorical moves and steps of academic texts [28]. A rhetorical move is a section of the text that represents a particular communicative function and incorporates functional and semantic elements of texts with specific aims [9]. This type of assessment is thus considered a descriptive method that permits comprehension of how the text is organized, with a clear didactic orientation [29].

Therefore, the appropriate organization of a text requires deep grammatical scrutiny in terms of the linguistic context. A number of these studies have dealt with the overall organization of research articles (RAs) [30], identifying different moves, such as: abstract, introduction, methods, results, and discussion. A detailed consideration of these studies is provided by Hsu et al. [25], where the necessary argumentative organization of the discussion and introduction moves is verified; thus, argumentative writing is an academic genre that forms part of RAs. Argumentative writing, likewise, forms part of the structure of other academic genres, such as dissertation projects [31].

In line with the described positions, a qualitative study by Arroyo et al. [32] focuses specifically on assessing the moves and the steps of argumentative essays for scientific purposes of undergraduate Education students, identifying: (a) the absence of a clear description of the topic of interest in the introduction; (b) a scarcity of quotes from research and experts; (c) the lack of a clearly differentiated progression of ideas, leading to a conclusion backed up by defining reasons; and (d) the lack of bibliographical references.

The findings coincide with those of other qualitative analyses on text organization, which affirm that no clear structure can be identified therein [33] or confirm the inability to present research in order to strengthen an opinion [34]. In this same line, after following a web-based teaching process, Luna et al. [35], applying the McNemar and Chi-Square test to compare nominal variables and ANOVA of repeated measures to compare interval variables, indicate that university students still require more support to expand their skills in order to integrate argumentative summaries.

As such, the literature indicates the necessary training for university students in general for managing strategies and tools that guide the organization of argumentative writing. There is an emphasis on communicating findings in writing in an argumentative manner, in which writing metacognition assessment undoubtedly plays an essential part. 


\subsection{Assessing Writing Metacognition and Its Dimensions}

Currently, writing is defined as a complex process, requiring the activation of a metacognitive dimension, to achieve certain objectives within diverse sociocultural contexts [36]. In this regard, the Metasociocognitive Model for writing [37] underlines the need for comprehension of the overall writing process from the cognitive, sociocultural, and motivational perspectives. This multidimensional understanding of writing stands out in the literature on the subject [4,38-41]. Therefore, writing metacognition-understood as "the awareness and ability of learners to take responsibility and control to construct" [42], p. 183 writing knowledge-enables improvement in the construction of an argumentative essay in the academic context [43].

A qualitative study by Arroyo [44] assesses writing from the metasociocognitive perspective and identifies metacognitive dimensions expressed by degree students. These dimensions, identified in other university studies, are:

(a) Writing planning, transcription, and revision at the university level, examining whether the factors arose through exploratory factor analysis [45].

(b) Writing control, applying Cronbach's alpha and $t$-tests [46].

(c) Writing self-regulation, applying ANCOVA analysis [47-49].

(d) Self-efficacy and achievement of goals in writing, applying exploratory factor analysis and confirmatory factor analysis [50,51].

(e) Consideration of the audience, applying qualitative analyses [52].

(f) The use of technologies that convey written communications, applying qualitative analysis [53].

In short, the assessment of writing metacognition promotes awareness, not only of cognitive processes and sociocultural writing conditions, but also of motivational factors. Self-efficacy is an interesting motivational factor guiding the organization of argumentative writing, as it encourages writers to believe that they can be successful [54].

\subsection{Assessing Writing Self-Efficacy}

Writing self-efficacy is defined as a motivational construct referring to the feeling of competence in carrying out diverse writing tasks [55].

In the university context, different studies $[18,45,51,56]$ show the writing tasks affected by the feeling of self-efficacy, such as linguistic tasks, writing self-regulation, text organization, planning, and revision. In addition, a correlation between self-efficacy and other motivational factors, such as apprehension, attitudes towards writing, conception, conventions, and emotional self-control in writing, has been confirmed by applying Pearson's correlation $[57,58]$.

Other studies assess writing self-efficacy in learning contexts, showing a correlation, using Spearman's rank, between self-efficacy and writing metacognition, along with the fact that there is a significant increase in self-efficacy when following a didactic writing process [19-21].

The studies alluded to state "the relationship of writing self-efficacy to both writing processes and outcomes" [54]. The purpose of this study is to validate a web-based instruction model for improving argumentative writing self-efficacy and promoting writing metacognition and text organization.

\subsection{Web-Based and Genre-Based Writing Instruction Models}

Some higher education studies draw attention to the effects of internet technologies on argumentative writing $[59,60]$ and encourage their use to promote writing learning at the university level. Nevertheless, this study focuses on software or digital systems designed for the teaching and assessment of writing, that is, web-based writing instruction (hereinafter WBWI), understood as a technological environment for writing instruction in which applications, tools, and resources are integrated into a pedagogical system that guides and supports writing instruction and assessment in their many dimensions [61,62]. 
Different studies illustrate how WBWI can be implemented at the university level with positive results (see Table 1).

Table 1. Current studies illustrating how WBWI can be implemented at the university level.

\begin{tabular}{ccccc}
\hline Quote & Genre & WBWI & Dimensions Assessed & Design \\
\hline [63] & Research articles & RWT & Metacognition & $\begin{array}{c}\text { Experimental group: 11 } \\
\text { Statistics: Wilcoxon Signed-Rank text } \\
\text { Experimental group: } 33 \\
\text { Control group: } 35\end{array}$ \\
[35] & Argumentative writing & Moodle & $\begin{array}{c}\text { Arguments, degree of } \\
\text { integration, number of words }\end{array}$ & $\begin{array}{c}\text { Statistics: McNemar and Chi-Square test } \\
\text { and ANOVA }\end{array}$ \\
[64] & Argumentative writing & C-SAW & $\begin{array}{c}\text { Number of arguments, } \\
\text { knowledge of components of } \\
\text { an argument, knowledge of the } \\
\text { subject and changes in } \\
\text { epistemic beliefs }\end{array}$ & $\begin{array}{c}\text { Experimental group: 23 } \\
\text { Statistics: ANOVA and ANCOVA }\end{array}$ \\
[65] & Argumentative writing & MI Write & Rhetorical moves & $\begin{array}{c}\text { Experimental group: 559 } \\
\text { Statistics: Multilevel modeling }\end{array}$ \\
\hline
\end{tabular}

RWT: The Research Writing Tutor was designed to help students acquire knowledge about the research article genre and develop research writing competence. C-SAW: the Computer-Supported Argumentative Writer is an online authoring software embodying design principles derived from theories on written argumentation, self-regulation, and conceptual change. MI Write: A web-based interactive learning environment that supports a number of interactions between teachers and students.

The aforementioned studies highlight the effects of WBWI on determined dimensions using varied methodologies. The findings of studies can depend on the teaching methods applied in combination with the internet technologies used. This study, however, focuses on a WBWI model that integrates the methodological model known as genre-based writing instruction (hereinafter GBWI) created by Sydney School. The teaching and learning cycle (TLC) [66] used in GBWI consists of four stages in which a particular text type is introduced, modeled, jointly practiced, and eventually individually performed by students.

GBWI is presented as an effective didactic model for promoting the teaching of university-level writing $[67,68]$ and some higher education studies use WBWI integrating the GBWI methodology (see Table 2).

Table 2. Studies illustrating how the GBWI methodology combined with WBWI can be implemented at the university level.

\begin{tabular}{|c|c|c|c|c|}
\hline Quote & Genre & WBWI & Dimensions Assessed & Design \\
\hline [27] & Argumentative writing & Moodle & $\begin{array}{l}\text { Metacognition } \\
\text { Argumentative Self-efficacy } \\
\text { Rhetorical moves and steps }\end{array}$ & $\begin{array}{l}\text { Experimental group: } 50 \text { Control } \\
\text { group: } 50 \\
\text { Statistics: parametric contrast } \\
\text { Content analysis }\end{array}$ \\
\hline [25] & & & Rhetorical moves & $\begin{array}{c}\text { Experimental group: } 25 \\
\text { Statistics: Kruskal-Wallis } \mathrm{H} \text { test }\end{array}$ \\
\hline [26] & Research articles & EJP-write system & $\begin{array}{l}\text { Relevance, format, reliability, } \\
\text { level, and timeliness }\end{array}$ & $\begin{array}{c}\text { Experimental group: } 32 \\
\text { Statistics: Pearson Correlation } \\
\text { and } t \text {-test }\end{array}$ \\
\hline [23] & & & Usability & $\begin{array}{c}\text { Experimental group: } 35 \\
\text { Statistics: Cronbach's Alphas }\end{array}$ \\
\hline [22] & Argumentative writing & Moodle & $\begin{array}{l}\text { Metacognition } \\
\text { Argumentative Self-efficacy } \\
\text { Rhetorical moves and steps }\end{array}$ & $\begin{array}{l}\text { Experimental group in L1 and L2: } 50 \\
\text { Control group in L1 and L2: } 50 \\
\text { Statistics: parametric contrast } \\
\text { Content analysis }\end{array}$ \\
\hline
\end{tabular}

EJP-write system: an interconnected writing system for academic journal writing in English developed on the basis of GBWI to teach and assist with journal writing in a user-friendly environment. 
The GBWI didactic model has been chosen to guide the argumentative writing in the present research for two reasons: (1) because it develops a methodology oriented to the organization of the text in a collaborative and autonomous way; and (2) because it proposes a clearly structured and simple model compared with others ([69] p. 151). Finally, it defines an "instructional chaining" process that describes the instructional episodes promulgated by expert teachers in the teaching of writing [70].

In addition, the studies cited in Table 2 highlight that using WBWI with the integration of the GBWI methodological model may be effective in improving structuring skills in argumentative writing for scientific dissemination.

Nevertheless, attention should also be paid to the need for more extensive and indepth testing regarding the effect of this methodological combination (WBWI and GBWI) on the metasociocognitive, motivational, and writing structure dimensions in a multilingual environment at higher academic levels.

\section{Materials and Methods}

To respond to the research questions, this study applies a quasi-experimental research design, with two measurements repeated pretest and post-test, for three dependent variables (see Table 3) along with an independent variable called the "Ensayo Científico Multilingüe" (Multilingual Scientific Essay)—hereinafter ECM—with a control group and an experimental group.

Table 3. Quasi-experimental research design.

\begin{tabular}{ccccc}
\hline \multirow{2}{*}{ Variable Measured } & \multicolumn{2}{c}{ Control Group } & \multicolumn{2}{c}{ Experimental Group } \\
\cline { 2 - 5 } & Pretest & Post-Test & Pretest & Post-Test \\
\hline Structure of the argumentative essay & 150 & 150 & 150 & 150 \\
\hline $\begin{array}{c}\text { Metacognition of cognitive and } \\
\text { sociocultural writing processes }\end{array}$ & 150 & 150 & 150 & 150 \\
\hline Self-efficacy in the argumentative essay & 150 & 150 & 150 & 150 \\
\hline Total & 450 & 450 & 450 & 450 \\
\hline
\end{tabular}

\subsection{Participants}

All participants in this study were native Spanish-speaking university students in the first year of a Primary Education degree in the faculty of education of a university in southern Spain.

Firstly, a group of 518 volunteer students were selected (age; M: 20.71, SD 4.081), of which 151 (29.2\%) were men (age, M: 20.99, SD: 4.078) and 367 (70.8\%) were women (age; M: 20.60, SD: 4.083). Secondly, a group of 150 students took part in a pretest and a post-test three months after the first tests were applied. This group acted as the control group, given that they did not undergo any didactic treatment for writing. Of the control participants, 36 (24\%) were men and 114 (76\%) were women. Their age ranged from 17 to 62 years $(M=21.48 ; S D=4.97)$. Lastly, a group of 150 students were offered the ECM as a complementary activity within a subject at the faculty of education. Of the experimental group participants, $41(27.33 \%)$ were men and $109(72.67 \%)$ were women. Their age ranged from 18 to 42 years $(M=21 ; \mathrm{SD}=4.54)$.

\subsection{Treatment: The ECM}

The ECM is a WBWI model available in a Moodle course (Modular Object-Oriented Dynamic Learning Environment) with multilingual environments [71] in Spanish, English, German, Italian, and Catalan (see Figure 1). Moodle is a learning management system (LMS) that "provides web-based interfaces that support a wide range of activities. These include forums, content resources, questionnaires, chats, assignments, and so on, which are, in general, sufficient for setting up standard courses. The LMS may also integrate 
other tools" ([72] p. 562). Therefore, Moodle provides appropriate software within the WBWI framework because it allows for the design and implementation of the teaching of writing in a technological context with resources, applications, and internet tools integrated into a pedagogical system used in other courses for the teaching of writing at universities $[22,27,35]$.

FASE 2: Desarrollo del Ensayo Cientifico Multilingüe PHASE 2: Development of the Scientific Multilingual Text PHASE 2: Entwicklung des wissenschaftlichen mehrsprachigen Textes FASE 2: Desenvolupament del Text Científic Multilingüe

Sesión 7 / Session 7 / Sessione 7 / Sessió 7

I Sesión 7 / Session 7 / Sessione 7/ Sessió 7

*. Plantilla II / Template II / Vorlage II / Modello II

*. Plantilla III / Template III / Vorlage III / Modello III

Q Foro

B Preguntas / questions / Fragen / Consultas / Preguntes

Sesión 8 / Session 8 / Sessione 8 / Sessió 8
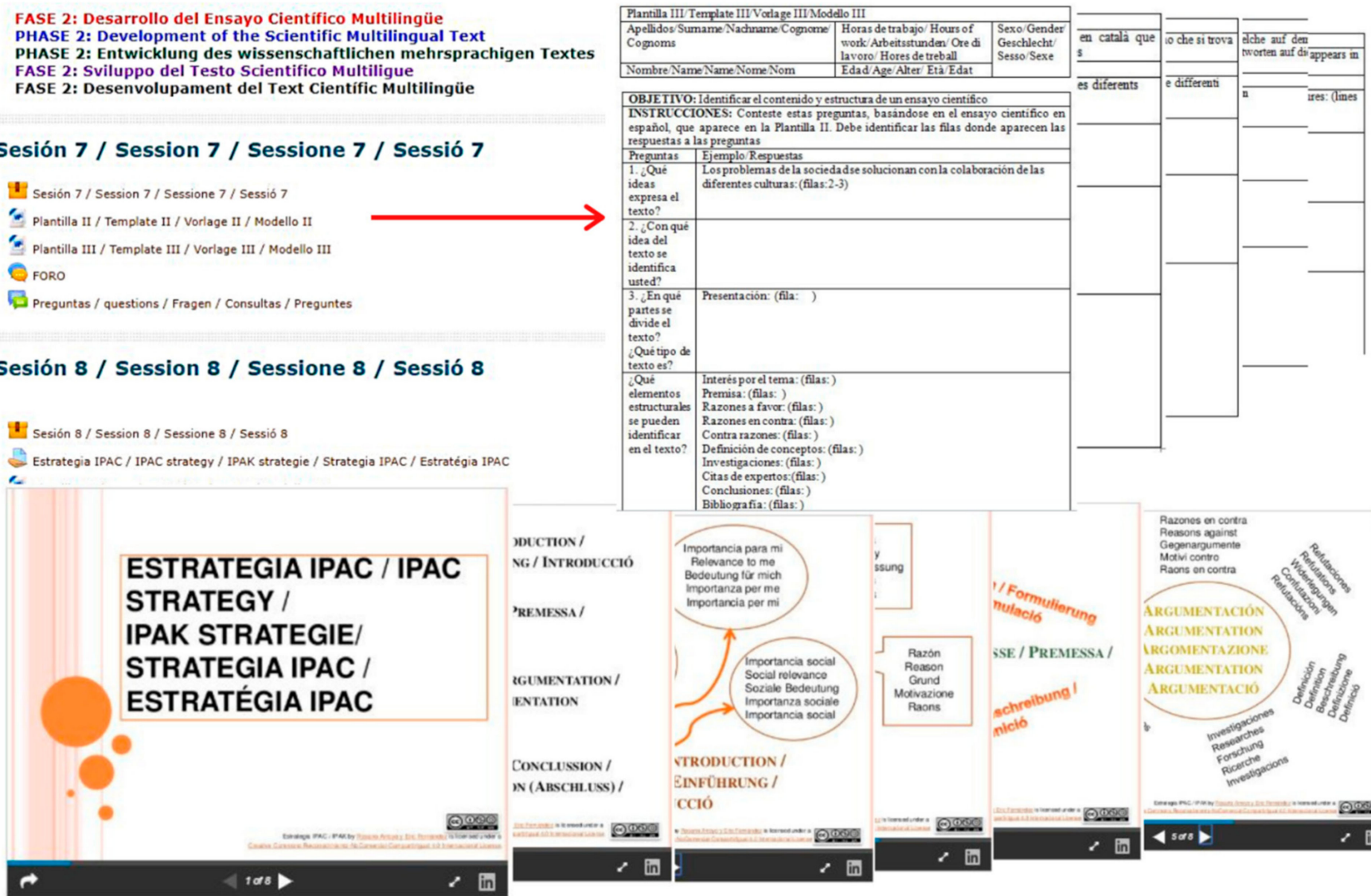

Figure 1. Phase 2 Interface, Sessions 7 and 8.

All the students registered on the ECM undertook the project of constructing an original argumentative essay autonomously and collaboratively over a three-month period, in 24 one-hour sessions, using a minimum of two languages (their native language and their first foreign language).

It is important to point out that when students access the ECM (via identification) they have an introductory section at their disposal with guides and short videos, which set out the learning objectives, the methodology to follow, and guidelines for organizing time. A teaching process is then initiated that develops in three phases:

Phase 1. Initial assessment: comprises sessions 1 to 5, which involve the application of instruments that measure writing metacognition and argumentative writing self-efficacy, and, furthermore, there is a request for the composition of an argumentative essay using the 'questionnaire' tool.

Phase 2. Comprises sessions 6 to 20, where the following stages are carried out, adapting the GBWI model (see Table 4).

Phase 3. Final Assessment: comprises sessions 21 to 24, where the same instruments used in Phase 1 are applied.

Interaction with the teacher occurs through messaging, chatrooms, and consultation forums. 
Table 4. Phase 2 of the ECM.

\begin{tabular}{|c|c|}
\hline jities & \\
\hline \multirow{3}{*}{$\begin{array}{l}\text { Constructing the scope. Comprises sessions } 6 \text { and } 7 \text { : in this stage, the students explore } \\
\text { the functionality and purpose of the scientific argumentative essay using the 'forum', } \\
\text { where responses are given to questions such as: "What is the social function of the } \\
\text { argumentative essay at the university level?" Furthermore, the students become aware } \\
\text { (metacognition) of the cognitive, sociocultural, and motivational writing dimensions } \\
\text { using the 'Lesson'. Furthermore, they have schematizations available in the ECM for } \\
\text { reflecting on the content and the structure of argumentative essays offered as models. } \\
\text { In addition, they can access scientific databases to search for information on the topic } \\
\text { of the argumentative essay they are going to write. Chat and messages are used to } \\
\text { resolve doubts related to database searches. }\end{array}$} & Applications: forum, chat, $\mathrm{m}$ \\
\hline & \\
\hline & \\
\hline \multirow{3}{*}{$\begin{array}{l}\text { Deconstruction. Comprises sessions } 8,9,10,11 \text {, and 12: this stage provides an analysis } \\
\text { of the structure (moves and steps) of the argumentative essay, applying a presentation } \\
\text { in Slideshare. Models of argumentative essays are also offered in order to identify their } \\
\text { structural moves and steps. In addition, schematizations are used for reflection and to } \\
\text { identify the argumentative structure of the texts presented as models, as well as to } \\
\text { check the structure of the student texts written in Phase } 1 \text {. Chats, messages, and a } \\
\text { forum are used to resolve doubts related to the structuring of the argumentative } \\
\text { writing. All of these activities create an individual metacognitive scaffolding on the } \\
\text { structuring of argumentative writing for scientific purposes. }\end{array}$} & \\
\hline & \\
\hline & $\begin{array}{l}\text { identifying the text's structure, } \\
\text { argumentative text models, and texts by } \\
\text { students themselves. }\end{array}$ \\
\hline
\end{tabular}

Join construction of the text. Comprises sessions 13,14,15,16,17, 18, and 19: this stage involves the planning, organization, writing of a draft, and revision of an argumentative essay with the collaboration of other students using messaging, forums, and a wiki. To do so, students are provided with a Prezi presentation of the writing process and outlines that guide the planning and organisation of the argumentative essay, along with self-instructions for supervising the writing process and a rubric that establishes the peer revision criteria for the first draft. These resources help stimulate awareness by students of their own capabilities for successfully tackling the writing of an argumentative essay; in other words, writing self-efficacy is stimulated. In turn, collaborative activities, supported and guided by technologies, create a metacognitive writing scaffolding at the group level that stimulates the planning of the text, negotiation in the writing of the first draft, and supervision and revision thereof. Thus, there is a stimulation of the knowledge and self-regulation of the group over the argumentative writing process.

Likewise, the students are provided with support for the construction of the argumentative text at orthographic, syntactic, and lexical levels in different languages.

Independent construction. Comprises session 20. In this stage, the students write an argumentative essay in a completely autonomous manner, based on what they have learnt. The activity is sent for revision using the Moodle task application.

Applications: chat forums, messages, a wiki, groupings, and Moodle tasks.

Tools: teaching guide on Scorm sessions and the presentation of the writing process on Prezi.

Resources: outlines for the planning and organization of the draft of the

argumentative text, along with rubrics, self-instructions, online translators, and dictionaries.

Applications: Moodle tasks.

Tools: Teaching guide on a Scorm session.

Resources: Template for writing the text.

Source: [27] (modified).

\subsection{Data Collection and Analysis Procedure}

The data collection instruments for the dependent variables, validation, and application procedures, as well as the analysis procedures, are explained below.

\subsubsection{Data Collection Instruments and Procedures}

The "Cuestionario sobre Metasociocognición en la Escritura" (CM, the Metasociocognitive Writing Questionnaire) (hereinafter, CM1 for the pretest and CM2 for the post-test) involves a written interview consisting of 20 closed questions, where students expressed their agreement with each item, with 0 being the most negative value and 100 the most positive. The items were designed for extracting information on the knowledge, self-regulation, and control of writing (see Appendix A).

The "Escala de Autoeficacia Escritora Argumentiva" (EA, the Argumentative Essay Self-Efficacy Scale) (hereinafter, EA1 for the pretest and EA2 for the post-test) includes 10 items, for each of which students were required to express their agreement, 0 being 
the most negative and 100 the most positive value. The items extract information on how students perceive the task of writing an argumentative essay (see Appendix B).

The procedure applied for the elaboration of both the CM and the EA was the expert discussion group (composed by the authors of this article) based on prior cognitive interviews created by Arroyo et al. [73], Karlen [48], and Meneses [74] in the case of CM; and Arroyo et al. [32] and MacArthur et al. [56] in the case of EA. Both instruments were subsequently applied to a group of 20 university students in a seminar where they were interviewed in order to check the appropriate formulation of each item at their own comprehension levels.

Another of the instruments applied was Text1 and Text2, consisting of writing an argumentative essay in Spanish on a given topic.

In all cases, the application procedure for the instruments was carried out in the presence of a teacher, with the students using the 'questionnaire' telematics tool, and with an approximate duration of between 10 and $20 \mathrm{~min}$ for EA and CM, respectively, and an hour for the argumentative essay.

\subsubsection{Instrument Validation}

The internal consistency of the CM and EA instruments, applied to 518 students, was verified with the value of Cronbach's Alpha coefficient, which was 0.846 for the total CM score (with a type element coefficient of 0.851 ) and 0.925 for EA (with a type element coefficient of 0.926). Furthermore, these data reveal a high accuracy, taking into account that there is no increase in these values if any item of the questionnaire is eliminated. This reliability was verified with the McDonald's coefficient omega values of 0.913 for CM and 0.857 for EA. Therefore, the plausibility of the instruments can be assumed, as no coefficient offered values under 0.784 for $\mathrm{CM}$ or 0.833 for EA, considering that these values are good indicators of the measurement of the reliability of an instrument.

The stability of the instruments was also verified, given that the completion of the questionnaire and the scale by a group made up of 260 university students took place at two different moments, without their being subject to any test that could modify their scores for each of the items considered. This group volunteered to take part in order to complete a retest three months after completing the first tests. Of the post-test participants, $68(26.2 \%)$ were men and $192(73.8 \%)$ were women. They were aged between 18 and 62 years $(M=21.38 ; \mathrm{SD}=4.79)$. A $t$-test was applied in order to see whether significant differences existed between this group and the initial group for the CM and EA variables, with no differences being found in any of the analyses. The results of the test-retest reveal Pearson's correlation coefficient values of 0.635 for CM and 0.614 for EA (both highly significant), which validates the stability of the two instruments.

This was followed by the application of exploratory factor analysis (EFA), selecting the principal component method as the factor extraction procedure for selecting the number of factors via Kaiser's rule. We then proceeded to rotate the axes via varimax orthogonal rotations and compared the rotated structure with other orthogonal rotations, such as the equamax. The EFA for CM (see Table 5) determined the existence of six factors for a total explained inertia of $58.465 \%$, comprising the following items: Factor 1, which explains $26.670 \%$ of the total inertia, referring to metacognitive control in writing $(8,14,15,17,19$, and 20); Factor 2, which explains $8.095 \%$ of the total inertia, referring to self-regulation in writing (items 12, 13, and 18); Factor 3, which explains the $6.986 \%$ of the total inertia, referring to knowledge about writing planning (items 1, 2, and 3); Factor 4, which explains $6.091 \%$ of the total inertia, referring to knowledge about writing transcription (items 4 and 5); Factor 5, which explains 5.526\% of the total inertia, referring to knowledge about writing revision (items 6, 7, and 16); and Factor 6, which explains 5.098\% of the total inertia, referring to knowledge about the audience (items 9, 10, and 11). These factors confirm the metacognitive dimensions of writing from the metasociocognitive perspective presented in the background section. 
Table 5. Components of each factor in the factorial structure of CM.

\begin{tabular}{|c|c|c|c|c|c|c|c|}
\hline \multirow{3}{*}{$\begin{array}{l}\text { F1 } \\
26.67 \%\end{array}$} & Items & 8 & 14 & 15 & 17 & 19 & 20 \\
\hline & Factor loading & 0.545 & 0.593 & 0.566 & 0.616 & 0.674 & 0.608 \\
\hline & $\%$ communality & 50 & 54.7 & 50.3 & 54.9 & 49.3 & 42.8 \\
\hline \multirow{3}{*}{$\begin{array}{l}\text { F2 } \\
8.10 \%\end{array}$} & items & 12 & 13 & 18 & & & \\
\hline & Factor loading & 0.592 & 0.655 & 0.758 & & & \\
\hline & $\%$ communality & 54.6 & 58.5 & 63.8 & & & \\
\hline \multirow{3}{*}{$\begin{array}{l}\text { F3 } \\
6.99 \%\end{array}$} & items & 1 & 2 & 3 & & & \\
\hline & Factor loading & 0.751 & 0.793 & 0.718 & & & \\
\hline & $\%$ communality & 66 & 73.7 & 57.7 & & & \\
\hline \multirow{3}{*}{$\begin{array}{l}\mathrm{F} 4 \\
6.09 \%\end{array}$} & items & 4 & 5 & & & & \\
\hline & Factor loading & 0.786 & 0.765 & & & & \\
\hline & $\%$ communality & 69.3 & 69.5 & & & & \\
\hline \multirow{3}{*}{$\begin{array}{l}\text { F5 } \\
5.53 \%\end{array}$} & items & 6 & 7 & 16 & & & \\
\hline & Factor loading & 0.805 & 0.764 & 0.536 & & & \\
\hline & $\%$ communality & 71.9 & 67.1 & 55.4 & & & \\
\hline \multirow{3}{*}{$\begin{array}{l}\text { F6 } \\
5.10 \%\end{array}$} & items & 9 & 10 & 11 & & & \\
\hline & Factor loading & 0.765 & 0.345 & 0.660 & & & \\
\hline & $\%$ communality & 63.1 & 37.5 & 59.1 & & & \\
\hline
\end{tabular}

For its part, the EFA for EA with self-values higher than 1 determined a single factor with a total explained inertia of $60.016 \%$. Taking into account a self-value higher than 0.75 , this total inertia increases to $67.71 \%$ with two factors appearing. Factor 1 comprises the first five items, which explain $60.2 \%$ of the inertia. Factor 2 comprises the last five items, which only explain $7.55 \%$ of the inertia, pointing more to the assumption of a single factor.

Finally, a confirmatory factor analysis (CFA) was carried out via structural equation models, and by calculating the degrees of absolute, incremental, and parsimony fit of the models, the results of which appear in Table 6. A good fit was observed in the case of CM, whereas two highly significant values appear in EA due to its inadequacy in the case of two factors: a CMIN/DF $>3$ represents an inadequate adjustment of the model [75]. A similar issue occurred with the RECMA value of 0.09 [76]. This all confirms the existence of a single factor for EA, which coincides with the results of MacArthur et al. [56].

Table 6. Confirmatory factor analysis (CFA) for CM and EA.

\begin{tabular}{|c|c|c|c|c|c|c|c|c|}
\hline & \multicolumn{3}{|c|}{ Absolute Adjustment } & \multicolumn{4}{|c|}{ Incremental Adjustment } & \multirow{2}{*}{$\begin{array}{c}\text { Parsimony Adjustment } \\
\text { PNFI }\end{array}$} \\
\hline & $x^{2}$ & GFI & CMIN/DF & RMSEA & NFI & IFI & CFI & \\
\hline Ideal value & $p<0.05$ & $0.9-1$ & $<3$ & $<0.05$ & $>0.9$ & $>0.9$ & $0-1$ & High value \\
\hline $\mathrm{CM}$ & $p=0.000$ & 0.929 & 2.511 & 0.054 & 0.854 & 0.907 & 0.906 & 0.697 \\
\hline EA & $p=0.000$ & 0.938 & 5.104 & 0.090 & 0.945 & 0.955 & 0.955 & 0.714 \\
\hline
\end{tabular}

GFI, Goodness of Fit Index; RMSEA, Root Mean Square Error of Approximation; NFI, Normed Fit Index; IFI, Incremental Fit Index; CFI, Comparative Fit Index; PNFI, Parsimony Normed Fit Index.

Finally, the McDonald's omega [14] and Cronbach's alpha coefficient values confirm the factorial structure represented above (see Table 7).

\subsubsection{Data Analysis}

The argumentative essays written by the students were subjected to the content analysis method. This investigation, based on a previous study by Arroyo [44], saw the 
carrying out of an initial exploration of all of the argumentative essays written by the students, coding them in Nvivo11. The rhetorical steps outlining the argumentative essay moves are described in Table 8, where the rhetorical steps show a linear-cyclical sequence.

Table 7. McDonald's omega and Cronbach's alpha coefficients.

\begin{tabular}{cccc}
\hline & Items & Alpha & Omega \\
\hline F1 & 6 & 0.725 & 0.772 \\
\hline F2 & 3 & 0.701 & 0.709 \\
\hline F3 & 3 & 0.726 & 0.798 \\
\hline F4 & 2 & 0.702 & 0.751 \\
\hline F5 & 3 & 0.455 & 0.627 \\
\hline F6 & 3 & 0.638 & 0.749 \\
\hline Total & 20 & 0.846 & 0.913 \\
\hline
\end{tabular}

Table 8. Linear-cyclical structure of the argumentative essay.

\begin{tabular}{|c|c|c|}
\hline Rhetorical Moves & Linear Rhetorical Steps (Code) & Cyclical Rhetorical Steps (Code) \\
\hline \multirow{4}{*}{ Introduction } & Presentation of the subject $(\mathrm{P})$ & \multirow{4}{*}{ Quotes (Q) } \\
\hline & Personal interest (PI) & \\
\hline & Social relevance (SR) & \\
\hline & Innovations (I) & \\
\hline Premise & Formulation of premise (FP) & $\begin{array}{l}\text { Definition of concepts (DCP) } \\
\text { Premise quotes (PQ) }\end{array}$ \\
\hline \multirow{3}{*}{ Argumentation } & Reasons for (RF) & \multirow{3}{*}{$\begin{array}{l}\text { New concept definition (NCD) } \\
\text { Research quotes (RQ) }\end{array}$} \\
\hline & Reasons against (RA) & \\
\hline & Refutations (R) & \\
\hline \multirow{3}{*}{ Conclusion } & Reason summary (RS) & \\
\hline & Definitive reason (DR) & \\
\hline & Projection (A) & \\
\hline Bibliography & Bibliographical references (BR) & \\
\hline
\end{tabular}

This exploration confirmed the category system that describes the structure of argumentative essays by university students, validated [27,73] and replicated [22,27,32] in different studies.

The main challenges faced in the observation and identification of rhetorical moves and steps expressed in the argumentative essays of the students were the following:

Challenge 1. Determining the units of meaning in which to identify the argumentative rhetorical steps. The universe of documents to be analyzed was made up of 300 templates on which students wrote their argumentative, pretest, and post-test essays; each template had an average length of one page. In order to observe and analyze all the information contained in the universe of documents, context units were identified. Each template containing an argumentative essay written by a student was considered a context unit. Afterwards, registration units were established, that is, the sentences or paragraphs that provided complete information about some rhetorical argumentative step of a scientific nature as presented in Table 8.

Challenge 2. Classifying and reducing the information referring to rhetorical steps and moves. The classification of the contents of each context unit was carried out by careful 
reading, by the first researcher named in this article, of the 300 context units and assigning to each registration unit a code referring to a rhetorical step of the proposed category system (see Table 8). Finally, a recount rule was added, which is the number of times that each rhetorical step in each of the essays is expressed. The frequency of each move was obtained by adding the frequencies of all of the steps contained in that move.

Challenge 3. Establishing the inter-reliability of the frequencies of the different rhetorical argumentative moves identified. First, a second exploration was carried out by the second researcher named in this article. In order to apply the same procedures and criteria in the examinations, both researchers coded 10 argumentative essays in a collaborative way. Researcher 2 subsequently coded the 300 context units independently. Second, the frequencies obtained by each researcher in each argumentative structural move were classified as either low (frequencies within the range 0-3), medium (frequencies within the range 4-6), and high (frequencies greater than 7). The agreement between the frequencies of each argumentative rhetorical move, made up of the sums of the rhetorical steps, was greater than 90\% when applying the Kappa index $[77,78]$ (see Appendix C). Finally, discrepancies detected within an interval were resolved by joint exploration by researcher 1 and researcher 2. When the discrepancies in frequencies occurred at different intervals, in this case a third researcher, trained in this type of analysis, performed an examination of the context unit in question and resolved the issue in consensus with researchers 1 and 2.

Finally, the quantitative analysis of the data took place in the following manner. Firstly, descriptive statistics were used to compare the pretest and post-test measurements. Secondly, the normality test was carried out with the Shapiro-Wilk statistic. Then, a parametric contrast test was completed for related samples and the Wilcoxon signed-rank test was carried out on the pretest and post-test variables. The effect size was also calculated by applying Cohen's $d$. This same procedure was repeated for the three measured variables, both for the experimental group and the control group.

\section{Results}

To respond to the questions raised by this study, we first present the different measurements, before and after the application of the ECM, of each of the rhetorical moves and steps of the essays (see Table 9) for the experimental group.

Table 9. Difference in mean frequencies of rhetorical moves and steps and the contrast for the experimental group.

\begin{tabular}{|c|c|c|c|c|c|c|c|}
\hline \multirow{2}{*}{ Variables } & \multicolumn{2}{|r|}{ Pretest } & \multicolumn{2}{|r|}{ Post-Test } & \multirow{2}{*}{ Difference } & \multirow{2}{*}{$p$} & \multirow{2}{*}{ Effect Size } \\
\hline & Mean & Standard Deviation & Mean & Standard Deviation & & & \\
\hline Text & 8.03 & 2.152 & 15.84 & 3.857 & $7.813 \mathrm{a}$ & $0.000 \mathrm{a}$ & 1.7813 \\
\hline Introduction & 3.57 & 1.282 & 7.44 & 2.841 & $3.873 \mathrm{~b}$ & $0.000 \mathrm{~b}$ & \\
\hline $\mathrm{P}$ & 1.88 & 0.665 & 3.43 & 1.905 & $1.547 \mathrm{~b}$ & $0.000 \mathrm{~b}$ & \\
\hline PI & 0.60 & 0.655 & 1.85 & 1.453 & $1.253 \mathrm{~b}$ & $0.000 \mathrm{~b}$ & \\
\hline SR & 1.00 & 0.777 & 0.88 & 0.859 & $-0.120 b$ & $0.161 \mathrm{~b}$ & \\
\hline I & 0 & 0.000 & 0.17 & 0.374 & $0.167 \mathrm{~b}$ & $0.000 \mathrm{~b}$ & \\
\hline Q & 0.09 & 0.282 & 1.11 & 1.065 & $1.027 \mathrm{~b}$ & $0.000 \mathrm{~b}$ & \\
\hline Premise & 0.77 & 0.798 & 0.82 & 0.836 & $0.053 \mathrm{~b}$ & $0.569 \mathrm{~b}$ & \\
\hline FP & 0.71 & 0.805 & 0.54 & 0.526 & $-0.173 \mathrm{~b}$ & $0.028 \mathrm{~b}$ & \\
\hline DCP & 0.05 & 0.225 & 0.28 & 0.557 & $0.227 \mathrm{~b}$ & $0.000 \mathrm{~b}$ & \\
\hline PQ & 0.05 & 0.225 & 0 & 0 & $-0.053 \mathrm{~b}$ & $0.004 \mathrm{~b}$ & \\
\hline Argumentation & 2.30 & 1.384 & 3.96 & 1.626 & $1.660 \mathrm{~b}$ & $0.000 \mathrm{~b}$ & \\
\hline $\mathrm{RF}$ & 1.60 & 1.105 & 1.00 & 0.835 & $-0.600 \mathrm{~b}$ & $0.000 \mathrm{~b}$ & \\
\hline RA & 0.28 & 0.451 & 0.77 & 0.680 & $0.487 \mathrm{~b}$ & $0.000 \mathrm{~b}$ & \\
\hline
\end{tabular}


Table 9. Cont.

\begin{tabular}{cccccccc}
\hline \multirow{2}{*}{ Variables } & \multicolumn{2}{c}{ Pretest } & Post-Test & Difference & $\boldsymbol{p}$ & Effect Size \\
\cline { 2 - 5 } & Mean & Standard Deviation & Mean & Standard Deviation & & $0.000 \mathrm{~b}$ \\
\hline $\mathrm{R}$ & 0 & 0 & 0.34 & 0.475 & $0.340 \mathrm{~b}$ & $0.000 \mathrm{~b}$ \\
\hline RQ & 0.31 & 0.465 & 0.85 & 0.639 & $0.540 \mathrm{~b}$ & $0.000 \mathrm{~b}$ \\
\hline NCD & 0.05 & 0.225 & 1.00 & 0.890 & $0.947 \mathrm{~b}$ & $0.000 \mathrm{~b}$ \\
\hline Conclusion & 1.34 & 1.048 & 2.91 & 1.353 & $0.567 \mathrm{~b}$ & $0.063 \mathrm{~b}$ \\
\hline RS & 0.25 & 0.436 & 0.17 & 0.374 & $0.087 \mathrm{~b}$ & $0.000 \mathrm{~b}$ \\
\hline DR & 0.20 & 0.401 & 0.60 & 0.492 & $1.400 \mathrm{~b}$ & $0.000 \mathrm{~b}$ \\
\hline BR & 0.89 & 0.807 & 2.14 & 1.147 & $0.660 \mathrm{~b}$ & $0.000 \mathrm{~b}$ \\
\hline
\end{tabular}

a. $t$-test for related samples. b. Wilcoxon signed-rank test for related samples.

An increase in the means in the structuring of the argumentative essay variable (hereinafter Text) of more than six points can be appreciated. An increase in the means in all of the rhetorical moves was also observed. Following this, highly significant differences were observed $(p<0.001)$, both in the total frequencies of the Text (with an effect size of 1.78) and in all of the rhetorical moves, except for Premise. Taking into account that "Cohen's $d$ values typically range between 0 and 2 and, although they can reach infinity, a Cohen's $d$ size of 0.2 to 0.3 represents a small effect but is considered to be a large effect" ([79] p. 173), an effect size of 1.78 allows us to consider that the effects produced by the ECM on the argumentative structuring of an essay of a scientific nature are very remarkable.

Highly significant differences were observed in all of the steps, with the exception of: (a) social relevance (SR); (b) formulation of premise (FP); (c) reasons for (RF); and (d) reason summary (RS).

Table 10 shows all the different $\mathrm{CM}$ measurements for the total and for the mean pondered by the factor loadings as well as for each of the factors. Likewise, the different measurements of the EA were studied, both for the total and for the mean pondered by the factor loadings.

Table 10. Descriptive and contrast measurements of the experimental group in the CM and EA variables.

\begin{tabular}{|c|c|c|c|c|c|c|c|}
\hline \multirow{2}{*}{ Variables } & \multicolumn{2}{|r|}{ Pretest } & \multicolumn{2}{|r|}{ Post-Test } & \multirow{2}{*}{ Difference } & \multirow{2}{*}{$p$} & \multirow{2}{*}{ Effect Size } \\
\hline & Mean & Standard Deviation & Mean & Standard Deviation & & & \\
\hline CM.PM & 68.83 & 10.196 & 75.04 & 10.662 & $6.211 \mathrm{a}$ & $0.000 \mathrm{a}$ & 0.7040 \\
\hline CM.TOTAL & 1373.7 & 201.513 & 1496.37 & 211.37 & $122.671 \mathrm{a}$ & $0.000 \mathrm{a}$ & 0.6982 \\
\hline CM.F1 & 75.09 & 10.810 & 79.58 & 11.014 & $4.488 \mathrm{~b}$ & $0.000 \mathrm{~b}$ & \\
\hline CM.F2 & 65.12 & 16.495 & 74.32 & 15.494 & $9.208 \mathrm{~b}$ & $0.000 \mathrm{~b}$ & \\
\hline CM.F3 & 66.83 & 15.551 & 75.20 & 14.538 & $8.369 \mathrm{~b}$ & $0.000 \mathrm{~b}$ & \\
\hline CM.F4 & 76.05 & 15.318 & 80.03 & 14.026 & $3.977 \mathrm{~b}$ & $0.000 \mathrm{~b}$ & \\
\hline CM.F5 & 60.23 & 16.415 & 67.25 & 14.464 & $7.020 \mathrm{~b}$ & $0.000 \mathrm{~b}$ & \\
\hline CM.F6 & 70.17 & 14.503 & 74.36 & 14.063 & $4.191 \mathrm{~b}$ & $0.000 \mathrm{~b}$ & \\
\hline EA.PM & 60.81 & 13.153 & 67.80 & 13.482 & $6.996 \mathrm{a}$ & $0.000 \mathrm{a}$ & 0.6593 \\
\hline EA.TOTAL & 608.37 & 130.703 & 677.07 & 135.016 & $68.700 \mathrm{a}$ & $0.000 \mathrm{a}$ & 0.6528 \\
\hline
\end{tabular}


Firstly, a homogeneous increase of over six points can be appreciated in both instruments (CM and EA). Secondly, an increase can also be observed in all of the CM factor means.

Highly significant $(p<0.001)$ differences were observed for both CM and EA. These significant differences furthermore appear, in mean and total scores, with effect sizes greater than 0.65 , along with the scores for the factors.

There is, furthermore, a greater difference in the following factors: F2, referring to writing self-regulation; F3, referring to writing planning; and F5, referring to the writing revision process, with a difference of greater than seven points.

On the other hand, fewer differences were appreciated in the following Factors: F4, referring to the writing transcription process; F6, referring to the consideration of the audience; and F1, referring to metacognitive control in writing, with differences of less than five points.

Lastly, the significant differences in the $\mathrm{CM}$ and EA variables and the total frequencies of the rhetorical moves of the Texts for the control group were verified (see Table 11).

Table 11. Descriptive measurements and the contrast for related samples in the control group.

\begin{tabular}{|c|c|c|c|c|c|c|c|}
\hline \multirow{2}{*}{ Variables } & \multicolumn{2}{|r|}{ Pretest } & \multicolumn{2}{|r|}{ Posttest } & \multirow{2}{*}{ Difference } & \multirow{2}{*}{$p$} & \multirow{2}{*}{ Effect Size } \\
\hline & Mean & Standard Deviation & Mean & Standard Deviation & & & \\
\hline $\mathrm{CM}$ & 1359.67 & 236.293 & 1391.98 & 268.407 & 32.313 & 0.055 & 0.1578962 \\
\hline EA & 589.67 & 149.779 & 608.15 & 150.356 & 18.473 & 0.060 & 0.1546880 \\
\hline Text & 7.41 & 3.458 & 7.09 & 2.888 & -0.313 & 0.319 & -0.0814891 \\
\hline
\end{tabular}

It can be observed that there are no significant differences for any of the variables between the pretest and post-test in the control group.

Furthermore, the application of the $t$-test (see Table 12) verified that there were no significant differences between the pretest measurements of the control group and the experimental group, demonstrating that the groups began from homogeneous positions in relation to the measured learning process. Lastly, significant differences were also confirmed between the control group and the experimental group in the post-test. These contrasts all confirm that the significant differences brought to light between the pretest and post-test measurements of the variables in the experimental group may be attributable to the effect of the ECM.

Table 12. Contrast for related samples between the control group and the experimental group.

\begin{tabular}{ccccc}
\hline $\mathbf{z}$ & Difference & Standard Deviation & $p$ & Effect Size \\
\hline CM-PRE EXP./CM-PRE CONTROL & 19.667 & 300.700 & 0.424 & 0.0654042 \\
\hline CM-POST EXP./CM-POST CONTROL & 110.307 & 331.787 & $0.000 * *$ & 0.3324632 \\
\hline EA-PRE EXP./EA-PRE CONTROL & 18.687 & 193.915 & 0.240 & 0.0963669 \\
\hline EA-POST EXP./EA-POST CONTROL & 68.913 & 192.458 & $0.000 * *$ & 0.3580677 \\
\hline Text-PRE EXP./Text-PRE CONTROL & 0.620 & 4.140 & 0.069 & 0.1319429 \\
\hline Text-POS TEXP./Text-POST CONTROL & 8.747 & 4.699 & $0.000^{* *}$ & 1.8614598 \\
\hline \multirow{2*}{*}{$p<0.001}$. & & &
\end{tabular}

\section{Discussion}

Regarding the first question, it can be established that this study confirms the significant increase in the production of all rhetorical moves of an argumentative essay, namely: introduction, formulation of premise, argumentation, conclusion, and bibliography. In the same vein, the WBWI framework created by Palermo et al. [65] helps university students acquire knowledge of rhetorical moves, although these studies, and specifically all the 
structural moves of the argumentative texts written by the students, were not evaluated with the content analysis method.

These results also confirm the effectiveness of guiding the genre (in this case the argumentative genre) in university students applying GBWI, firstly by corroborating the results of research by Kuiper et al. [68], where a GBWI model is assessed in order to guide academic genres (despite the fact that WBWI was not used in this study and does not focus on the argumentative genre), and secondly by corroborating the results of Hsu et al. [25], who examine whether GBWI integrated into WBWI enhances the genre structure of the Introduction and Methods sections of RAs. They report a benefit, although their improvements are not significant. In the same vein, Lammers et al. [24] applying the GBWI methodology, to assess structural moves in research articles, with the results showing significant improvements in the comprehension thereof.

Furthermore, the results of this study confirm the findings of two other studies focused on the argumentative genre [22,27] where WBWI integrated into the GBWI model was applied at the university level. These studies show significant differences in the global structuring of the text, with smaller samples. However, it is worth noting that the pilot study [27], in which the ECM was applied, shows significant effects on the global argumentative structuring both in L1 and in L2.

Regarding the first question, another finding is the highly significant increase in the production of rhetorical steps, which are especially important as regards a scientific argumentative essay, such as: innovations, quotes/research, definitions of concepts, refutations, definitive reasons, and bibliographical references. These findings are partially corroborated by the study of Luna et al. [35], using a WBWI, where the results show an improvement in the number of reasons against in the written production of the study participants. In addition, the use of citations (whose frequency increased significantly in the present study) is a genre signal of quality scientific writing [80]. The listed findings highlight the effectiveness of the ECM on learning in the expression of the specific rhetorical steps that define the argumentative genre of a scientific nature beyond the results of other investigations conducted under similar conditions.

Hence, the study presented in this research paper adapts the GBWI model in a multilingual WBWI model for scientific argumentative communication, with a control group and an experimental group and valid and reliable assessment instruments with which the possibilities of the effectiveness of the GBWI and WBWI models can be enhanced.

The results of this research paper, in addition, show that the defining rhetorical steps of argumentative writing, such as reason summary, formulation of premise, and reasons for, do not present significant differences following the application of the ECM. This suggests that the ECM encourages, in an effective way, the production of the argumentative essay structure but, conversely, there is considerable difficultly in implementing certain defining structural steps of an argumentative essay. A possible explanation is the findings of Benetos et al. [64], who compared the writing of a group of students when using C-SAW or a text editor. The results show that the experimental group constructed arguments to a greater degree, but do not reveal differences in the knowledge of the components of the argument. Perhaps the students who followed the ECM failed to obtain complete knowledge of the argumentative writing structure, suggesting that it would be appropriate to review the didactic-technological processes of the ECM.

Regarding the question of whether the ECM has an effect on the written metacognition of students, it is firstly important to state that the reliability, stability, and factorial structure of the applied instrument were demonstrated. This validation permits it to be clearly put forward that, in relation to writing metacognition, the results demonstrate a significant increase following the application of the ECM and confirm the studies by Arroyo et al. [22,27], where WBWI is also used by applying the GBWI model known as EA and ECM; however, these studies did not evaluate the dimensions of writing metacognition. The results also confirm those of Cotos et al. [63], who demonstrate that WBWI, known as Research Writing Tutor (RWT), promotes the metacognitive processing of writers during the revision of 
research articles. However, this study did not focus on written argumentation, although it was assumed that it is a genre included in research articles [18,81]. Moreover, only one metacognitive dimension was evaluated (the revision of the text).

Regarding the question of whether an improvement in metacognitive writing affects the cognitive and sociocultural dimensions of writing differently, it was demonstrated that, for those students who implemented the ECM, there was an increase, above all, in awareness of the following dimensions: (a) writing self-regulation; (b) writing planning; and (c) writing revision. No precedents for these findings have been found in similar studies; therefore, this result provides innovative empirical support for one of the key assumptions of a metacognitive study at the university level, namely that knowledge of the cognitive dimensions of writing and writing self-regulation are correlated and compensatory [42].

Nevertheless, minor (though still significant) differences can be seen in knowledge of writing transcription, which is a cognitive dimension involving the grammatical dimension for mentally planned and organized ideas to be converted into text. This is explained because students use their mother tongue, so they start with a high command of grammar; thus, the differences in these learning experiences are less prominent. The ECM, furthermore, has a didactic-technological design focused on the construction of the argumentative text more than on grammatical errors, to which other studies, such as that by Eckstein et al. [77], are of interest. Other smaller (though significant) differences were also confirmed in consideration of the audience and in metacognitive control of writing (referring to the emotional control over writing). These finding are thus explained in the study by Magnifico [82], wherein the author conceptualizes the audience across distinct learning environments, showing that it is related to the motivation and interest shown towards writing.

In short, the ECM produces a greater effect on the awareness of written cognitive dimensions than on the sociocultural writing conditions, to which it would be appropriate to review the didactic-technological processes of the ECM.

In relation to self-efficacy in the argumentative essay, we confirmed a significant increase in the mean scores. With these results, it can be concluded that the ECM strengthens self-efficacy factors in the production of argumentative essays of a scientific nature. This serves to answer the last research question. These results are explained by the improvement in the structuring of the argumentative texts, as confirmed in studies that relate writing self-efficacy to writing performance $[54,57]$. In addition, these findings provide support for self-efficacy as a motivational construct supportive of online learner self-regulation [83], as previously stated, since the application of the ECM also significantly increased writing self-regulation. Finally, the consistency of these results is guaranteed by the demonstrated reliability and stability of the instrument applied to measure argumentative writing selfefficacy in this study. Similar studies in WBWI [32] and studies combining WBWI and GBWI [22,27] agree on the positive effects on argumentative writing self-efficacy.

The effects of the ECM described were confirmed upon verifying that: (a) both the control group and the experimental group started from equivalent measurements of the three variables in the pretest, meaning that the groups were homogeneous in relation to the writing dimensions assessed; (b) the control group did not show significant differences between the pretest and post-test measurements for all variables, meaning that the differences found in the experimental group were an effect of the ECM; and (c) the control group showed significant differences compared with the experimental group in the posttest measurements of all variables, meaning that the effects of the ECM on the experimental group produced significant changes in relation to those experienced by the control group, giving rise to heterogeneous groups in the writing dimensions assessed.

\section{Conclusions}

The recent perspectives of the multilingual movement in studies on written communication $[84,85]$ argue that learning contexts should increase the use of the different 
languages at the disposal of students, more than insisting on the achievement of a standard level of command of writing in each language. The ECM has been designed and is to be implemented under this premise and demonstrates an effect on the learning of: (a) writing metacognition and its cognitive and sociocultural dimensions; (b) self-efficacy in argumentative writing; and (c) the rhetorical moves and steps thereof. All of this is in relation to Education degree students using their native language (Spanish). It was also verified that the effect of the ECM increases the expression of rhetorical argumentative steps, such as innovations, research quotes, concept definitions, refutations, reasons, and bibliographical references. Further, the ECM shows itself to be effective at creating awareness of writing self-regulation, planning, and revision. These conclusions invite inquiry into how the ECM behaves when students write in their first or second foreign language. In this regard, a pilot study has already been developed [22], verifying the effect of the ECM on L1 and L2; however, the effect on all dimensions of metacognition, or all rhetorical steps, has not been evaluated, although it has enabled the establishing of very interesting pedagogical lines of action, collected in this version of the ECM.

In addition, it is important to note that this research, in addition to expanding the effectiveness of the multilingual WBWI technological model integrated into the GBWI didactic model, demonstrates the effectiveness of the ECM's "instructional channels" to guide argumentative writing as a scientific development skill important to university students. This is so because argumentative written communication plays an essential role in the construction and dissemination of knowledge in any academic field due to its persuasive power, used when it is intended to achieve the adherence of the scientific community of that field. Argumentative speech is used to demonstrate the truth of affirmations, the validity of methods and results, and the logic of findings, so that all of this can be evaluated [86]. Undoubtedly, the students who followed the ECM obtained a high level in the construction of their written argumentation, introducing the rhetorical argumentative steps of a scientific nature mentioned above. This new ability will help to improve both academic scores in all activities evaluated with argumentative essays and end-of-degree research projects. Checking how these argumentative skills acquired with the ECM are applied in academic work may be an interesting longitudinal investigation [87-89] for the future.

It would also be interesting in future research to investigate whether the skills acquired through the ECM in argumentative structuring, writing metacognition, and argumentative self-efficacy differ depending on the skills achieved in secondary education. For example, students who have developed textual interconnection skills in their argumentative writing [90] may be better able to learn both the structure of scientific argumentation shown by the ECM and to achieve new awareness of their knowledge of writing and new self-perceptions about their argumentative writing competence. In any case, in this study the academic background of the students was not considered in relation to their previous argumentative skills, although a significant amount of learning was found from their starting position (pretest position), which is attributable to the ECM since the control group showed no progress in this regard. Likewise, it was found that the control and experimental groups are homogeneous groups in relation to the argumentative structuring skills, writing metacognition, and argumentative self-efficacy in the pretest.

Furthermore, the study of Lust et al. [91] shows that internet use has an adverse effect on writing performance due to the complexity of the processes involved. These results contradict our results, which demonstrate that a methodologically well-structured WBWI model can considerably improve the argumentative writing dimensions of university students for scientific purposes. The reason for this positive effect on writing learning may be the trust the ECM generates in students as regards the use of internet technologies. Thus, if "students with higher confidence in using the internet express more preference towards exploring multiple sources of information, engaging in an inquiry activity, or probing the nature of knowledge in web-based learning environments" [92], these dispositions may certainly be causing the results described. 
It is important to draw attention to the fact that the conclusions put forward can only be established for the students in this study. It obviously not possible to make generalizations in other academic contexts; however, the evidence encourages the continued application of the ECM, with the introduction of certain innovations providing a more effective guide for university student training in argumentative written communication, and, in turn, its effect may be verified in students who use other languages. The results of the research in this study are applicable to the training of Primary Education teachers. The results may also be applicable to faculties of education and other types of faculties that work on argumentative texts for scientific purposes.

A number of innovations can be proposed in this regard, such as the design of an assessment and classification system integrated into the ECM that offers immediate feedback to students in the text construction process [93], with a view to reinforcing the structuring of the argumentative essay [34], as well as the syntactic and lexical correction thereof. These changes are aimed at helping teachers to precisely identify student needs because, as demonstrated in this study, these do not result from a complete awareness of the writing dimension and, furthermore, as shown in the study by Ferris et al. [94], linguistic backgrounds and levels of confidence may differ considerably. In addition, changes are proposed with the objective of offering more specific support with the design of mini sessions focused on specific dimensions of need. In this case, these dimensions of need are: (1) audience consideration; and (2) emotional self-control to boost concentration during the writing task.

Our research team is working to improve the ECM, contemplating the application of artificial intelligence [95-97] to guide the construction of scientific argument texts in different languages and disciplines, and to continue deepening the connections between motivation, metacognition, and writing performace [17].

Author Contributions: Conceptualization, R.A.G. and E.F.-L.; methodology, R.A.G., E.F.-L. and J.A.M.J.; software, R.A.G. and E.F.-L.; validation, R.A.G., E.F.-L. and J.A.M.J.; formal analysis, R.A.G., E.F.-L. and J.A.M.J.; investigation, R.A.G., E.F.-L. and J.A.M.J.; resources, R.A.G. and E.F.-L.; data curation, J.A.M.J.; writing—original draft preparation, R.A.G.; writing—review and editing, R.A.G. and E.F.-L.; supervision, R.A.G.; project administration, R.A.G.; funding acquisition, R.A.G. and E.F.-L. All authors have read and agreed to the published version of the manuscript.

Funding: This research was developed within the framework of ED.INVEST (HUM356) Research Groups financed by the Junta de Andalucía (Spain), with the project "Multilingual Communication and Citizenship Technologies" and the project "Accessible scientific writing course in Moodle to be taught in Spanish, German, English, Italian, and Catalan", financed by the Department of Planning Quality and Evaluation at the University of Granada. Reference PID14-05/Code 14-05.

Institutional Review Board Statement: Not applicable.

Informed Consent Statement: Not applicable.

Data Availability Statement: Not applicable.

Acknowledgments: We thank the reviewers and editors of this journal for considering the article for publication.

Conflicts of Interest: The authors declare no conflict of interest. 


\section{Appendix A. Cuestionario Sobre Metasociocognición de la Escritura (CM, Writing Metasociocognition Questionnaire)}

Cuestionario Sobre Metasociocognición de la Escritura (CM, Writing Metasociocognition Questionnaire)

\begin{tabular}{|c|c|}
\hline Factores/Factors & Ítems/Items \\
\hline \multirow{6}{*}{$\begin{array}{l}\text { Factor } 1 \\
\text { Control metacognitivo } \\
\text { (Metacognitive } \\
\text { control) }\end{array}$} & $\begin{array}{l}\text { 19. En los textos que escribo expreso mis propias ideas, sentimientos } \\
\text { y/o intereses } \\
\text { (In the texts I write I express my own ideas, feelings, and/or interests) }\end{array}$ \\
\hline & $\begin{array}{l}\text { 17. Cuando escribo un texto, me siento bien conmigo mismo y pienso } \\
\text { que ese texto es valioso } \\
\text { (When I write a text I feel good about myself and believe that the text is } \\
\text { of value) }\end{array}$ \\
\hline & $\begin{array}{l}\text { 20. En los textos que escribo soy yo el que decide dónde escribo, con } \\
\text { qué recursos, a quién escribo y qué código lingüístico utilizo } \\
\text { (In the texts I write I am the one who decides where I write, with what } \\
\text { resources, who I write for, and what linguistic code I use) }\end{array}$ \\
\hline & $\begin{array}{l}\text { 14. Cuando escribo un texto me planteo por qué estoy escribiendo, } \\
\text { cómo lo estoy haciendo y de lo que siento, para lograr un fin } \\
\text { (When I am writing a text I consider why I am writing, how I am doing } \\
\text { it, and how I feel about achieving a purpose) }\end{array}$ \\
\hline & $\begin{array}{l}\text { 15. Me concentro cuando escribo para lograr mis objetivos } \\
\text { (I concentrate when I write in order to achieve my objectives) }\end{array}$ \\
\hline & $\begin{array}{l}\text { 8. Cuando escribo un texto, sé por qué y para qué escribo ese texto } \\
\text { (When I write a text I know why I am writing it and for what purpose) }\end{array}$ \\
\hline \multirow{3}{*}{$\begin{array}{l}\text { Factor } 2 \\
\text { Auto-regulación } \\
\text { (Self-regulation) }\end{array}$} & $\begin{array}{l}\text { 18. Cuando escribo, utilizo algún truco o estrategia que haya } \\
\text { descubierto para que el texto me salga bien } \\
\text { (When I write a text I use tricks or strategies I have discovered to obtain } \\
\text { a good result) }\end{array}$ \\
\hline & $\begin{array}{l}\text { 13. Cuando escribo me digo a mí mismo lo que tengo que hacer para } \\
\text { escribir un buen texto } \\
\text { (When I write I tell myself what I need to do for it to be a good text) }\end{array}$ \\
\hline & $\begin{array}{l}\text { 12. Cuando escribo, aplico algunas estrategias para que mis textos } \\
\text { tengan unidad y para lograr terminarlos } \\
\text { (When I write I employ strategies in order to give unity to my texts and } \\
\text { to be able to finish them) }\end{array}$ \\
\hline \multirow{3}{*}{$\begin{array}{l}\text { Factor } 3 \\
\text { Planificación } \\
\text { (Planning) }\end{array}$} & $\begin{array}{l}\text { 2. Antes de escribir un texto hago algunas tareas previas } \\
\text { (Before writing a text I do some preliminary tasks) }\end{array}$ \\
\hline & $\begin{array}{l}\text { 1. Antes de escribir un texto dedico cierto tiempo a pensar } \\
\text { (Before writing a text I dedicate a certain amount of time to thinking) }\end{array}$ \\
\hline & $\begin{array}{l}\text { 3. Antes de escribir un texto decido la estructura de ese texto, la forma } \\
\text { y si voy a incluir componentes audiovisuales } \\
\text { (Before writing a text I decide its structure, format, and whether or not } \\
\text { to include audiovisual components) }\end{array}$ \\
\hline
\end{tabular}


Cuestionario Sobre Metasociocognición de la Escritura (CM, Writing Metasociocognition Questionnaire)

\begin{tabular}{|c|c|}
\hline Factores/Factors & Ítems/Items \\
\hline \multirow{2}{*}{$\begin{array}{l}\text { Factor } 4 \\
\text { Transcripción } \\
\text { (Transcription) }\end{array}$} & $\begin{array}{l}\text { 4. Cuando estoy escribiendo, utilizo normas de ortografía y } \\
\text { puntuación; construyo frases y párrafos y lo uno todo con nexos } \\
\text { (When I am writing I use standard spelling and punctuation; I make } \\
\text { sentences and paragraphs; and I link everything together } \\
\text { with connectors) }\end{array}$ \\
\hline & $\begin{array}{l}\text { 5. Cuando estoy escribiendo, aplico un determinado código lingüístico } \\
\text { y manejo adecuadamente los recursos que utilizo } \\
\text { (When I am writing I use a particular linguistic code and handle the } \\
\text { resources I use correctly) }\end{array}$ \\
\hline \multirow{3}{*}{$\begin{array}{l}\text { Factor } 5 \\
\text { Revision } \\
\text { (Review) }\end{array}$} & $\begin{array}{l}\text { 6. Cuando termino de escribir un texto, cambio palabras, frases, } \\
\text { párrafos, puntuación ... } \\
\text { (When I finish writing a text, I change words, sentences, paragraphs, } \\
\text { punctuation ... ) }\end{array}$ \\
\hline & $\begin{array}{l}\text { 7. Cuando termino de escribir un texto, cambio la estructura, los } \\
\text { aspectos formales y/o audiovisuales del texto } \\
\text { (When I finish writing a text, I change its structure and its formal } \\
\text { and/or audiovisual aspects) }\end{array}$ \\
\hline & $\begin{array}{l}\text { 16. Cuando escribo hay personas que me ayudan a escribir mejor } \\
\text { mi texto } \\
\text { (When writing a text, there are people there to help me improve it) }\end{array}$ \\
\hline \multirow{3}{*}{$\begin{array}{l}\text { Factor } 6 \\
\text { Audiencia(Audience) }\end{array}$} & $\begin{array}{l}\text { 9. Cuando escribo, me interesa saber quién leerá el texto } \\
\text { (When I write a text I want to know who is going to read it) }\end{array}$ \\
\hline & $\begin{array}{l}\text { 11. Cuando escribo, me planteo si el texto que escribo depende de las } \\
\text { personas que lo leerán } \\
\text { (When I write I consider whether the text depends on those who will } \\
\text { read it) }\end{array}$ \\
\hline & $\begin{array}{l}\text { 10. Hago escritos en colaboración con otras personas } \\
\text { (I write texts in collaboration with others) }\end{array}$ \\
\hline
\end{tabular}

Appendix B. Escala de AutoeficaciaEscritoraArgumentiva (EA, Argumentative Writing Self-Efficacy Scale)

\begin{tabular}{l} 
Escala de AutoeficaciaEscritoraArgumentiva (EA, Argumentative Writing Self-Efficacy Scale) \\
\hline Items \\
1. Puedo buscar y encontrar ideas para escribir un ensayo argumentativo y referenciarlas en \\
una bibliografía \\
(I can search for and find ideas for writing an argumentative essay and reference them in \\
a bibliography) \\
2. Puedo escribir un ensayo argumentativo bien organizado \\
(I can write a well-organized argumentative essay) \\
3. Puedo escribir un ensayo argumentativo con facilidad \\
(I can write an argumentative essay with ease) \\
4. Puedo escribir la premisa cuando escribo un ensayo argumentativo \\
(I can write the premise when writing an argumentative essay) \\
5. Puedo escribir razones, contra-razones y refutaciones para demostrar la premisa \\
(I can write arguments, counter-arguments, and refutations to demonstrate the premise) \\
\hline 6. Puedo escribir sin parar cuando escribo un ensayo argumentativo \\
(I can write continuously when writing an argumentative essay) \\
\hline
\end{tabular}


7. Puedo escribir una introducción y una conclusión cuando escribo un ensayo argumentativo (I can write an introduction and conclusion when writing an argumentative essay)

8. Puedo modificar los movimientos y los pasos estructurales cuando escribo un ensayo argumentativo

(I can modify movements and structural stages when writing an argumentative essay)

9. Puedo identificar errores gramaticales y corregirlos cuando escribo un ensayo argumentativo (I can identify grammatical errors and correct them when writing an argumentative essay)

10. Puedo expresar ideas, con mi propio estilo cuando escribo un ensayo argumentativo (I can express ideas in my own style when writing an argumentative essay)

\section{Appendix C. Kappa Concordance}

\begin{tabular}{lcccccc}
\hline Kappa Concordance & \multicolumn{3}{c}{ PRE-TEST } & & POST-TEST \\
\cline { 2 - 7 } & Kappa & LI IC 95\% & LS IC 95\% & Kappa & LI IC 95\% & LS IC 95\% \\
\hline Introduction & 0.91 & 0.76 & 1.00 & 0.90 & 0.74 & 1.00 \\
\hline Premise & 0.92 & 0.76 & 1.00 & 0.93 & 0.77 & 1.00 \\
\hline Argumentation & 0.90 & 0.74 & 1.00 & 0.90 & 0.75 & 1.00 \\
\hline Conclusion & 0.90 & 0.75 & 1.00 & 0.92 & 0.76 & 1.00 \\
\hline Bibliography & 0.90 & 0.75 & 1.00 & 0.94 & 0.78 & 1.00 \\
\hline
\end{tabular}

\section{References}

1. Divan, A.; Mason, S. A Programme-Wide Training Framework to Facilitate Scientific Communication Skills Development amongst Biological Sciences Masters Students. J. Furth. High. Educ. 2016, 40, 543-567. [CrossRef]

2. Guzmán-Simón, F.; García-Jiménez, E. Los hábitos lectoescritores en los alumnos universitarios. Rev. Electrón. Interuniv. Form. Profr. 2014, 17, 79-92. [CrossRef]

3. Mair, C. Using Technology for Enhancing Reflective Writing, Metacognition and Learning. J. Furth. High. Educ. 2012, 36, 147-167. [CrossRef]

4. Jakobs, E.M.; Perrin, D. Handbook of Writing and Text. Production; De Gruyter Mouton: Berlin, Germany, 2014; ISBN 978-3-11-022067-4.

5. Garrison, D.R. E-Learning in the 21st Century: A Framework for Research and Practice; Routledge: London, UK, 2011; ISBN 978-0-203-83876-1.

6. Bellhäuser, H.; Lösch, T.; Winter, C.; Schmitz, B. Applying a Web-Based Training to Foster Self-Regulated Learning-Effects of an Intervention for Large Numbers of Participants. Internet High. Educ. 2016, 31, 87-100. [CrossRef]

7. Martinez, C.T.; Kock, N.; Cass, J. Pain and Pleasure in Short Essay Writing: Factors Predicting University Students' Writing Anxiety and Writing Self-Efficacy. J. Adolesc. Adult Lit. 2011, 54, 351-360. [CrossRef]

8. Teng, F. Immediate and Delayed Effects of Embedded Metacognitive Instruction on Chinese EFL Students' English Writing and Regulation of Cognition. Think. Ski. Creat. 2016, 22, 289-302. [CrossRef]

9. Swales, J. Research Genres: Explorations and Applications; Cambridge University Press: New York, NY, USA, 2004; ISBN 978-0-521-53334-8.

10. Yim, S.; Warschauer, M. Web-Based Collaborative Writing in L2 Contexts: Methodological Insights from Text Mining. Lang. Learn. Technol. 2017, 21, 146-165.

11. Yücel, Ü.A.; Usluel, Y.K. Knowledge Building and the Quantity, Content and Quality of the Interaction and Participation of Students in an Online Collaborative Learning Environment. Comput. Educ. 2016, 97, 31-48. [CrossRef]

12. Fulcher, G. Practical Language Testing; Routledge: London, UK, 2013; ISBN 978-1-4441-2801-7.

13. Acal, C.; Aguilera, A.M.; Escabias, M. New Modeling Approaches Based on Varimax Rotation of Functional Principal Components. Mathematics 2020, 8, 2085. [CrossRef]

14. Alsubie, A.; Akhter, Z.; Athar, H.; Alam, M.; Ahmad, A.E.-B.A.; Cordeiro, G.M.; Afify, A.Z. On the Omega Distribution: Some Properties and Estimation. Mathematics 2021, 9, 656. [CrossRef]

15. Shah, M.A.A.; Mashwani, W.K.; Kumam, W.; Kumam, P.; Chesneau, C.; Jamal, F.; Ozel, G.; Sleem, H.S.; Khan, H.U. Application of Mixed Sampling to Real Life Data: A Case Study on Socio-Economic Determinants by Using SEM and CFA Techniques. Mathematics 2020, 8, 337. [CrossRef]

16. Meléndez, R.; Giraldo, R.; Leiva, V. Sign, Wilcoxon and Mann-Whitney Tests for Functional Data: An Approach Based on Random Projections. Mathematics 2021, 9, 44. [CrossRef]

17. Teng, L.S.; Zhang, L.J. Effects of Motivational Regulation Strategies on Writing Performance: A Mediation Model of Self-Regulated Learning of Writing in English as a Second/Foreign Language. Metacognition Learn. 2018, 13, 213-240. [CrossRef] 
18. Arroyo, R.; de la Hoz-Ruiz, J.; Montejo, J. The 2030 Challenge in the Quality of Higher Education: Metacognitive, Motivational and Structural Factors, Predictive of Written Argumentation, for the Dissemination of Sustainable Knowledge. Sustainability 2020, 12, 8266. [CrossRef]

19. Wilby, J. Motivation, Self-Regulation, and Writing Achievement on a University Foundation Programme: A Programme Evaluation Study. Lang. Teach. Res. 2020, 24, 1-24. [CrossRef]

20. Amin, E. A Correlational Study between Some Motivational Constructs and EFL Writing Performance in a Blended Learning Environment. Int. J. Engl. Linguist. 2019, 9, 238-248. [CrossRef]

21. Arroyo, R.; Jimenez-Baena, A.; Martinez-Sanchez, E. Interculturalidad en la Univeridad: Aprendizaje de competencias multilingües escritoras en entornos personales de aprendizaje. Rev. Int. Sobre Divers. E Identidad Educ. 2015, 2, 29-36.

22. Arroyo, R.; Fernández-Lancho, E.; de la Hoz-Ruiz, J. Technologies for Learning Writing in L1 and L2 for the 21st Century: Effects on Writing Metacognition, Self-Efficacy and Argumentative Structuring. J. Inf. Technol. Educ. Res. 2021, 20, 087-116. [CrossRef]

23. Lo, H.-Y.; Liu, G.-Z.; Wang, T.-I. Learning How to Write Effectively for Academic Journals: A Case Study Investigating the Design and Development of a Genre-Based Writing Tutorial System. Comput. Educ. 2014, 78, 250-267. [CrossRef]

24. Lammers, A.; Goedhart, M.J.; Avraamidou, L. Reading and Synthesising Science Texts Using a Scientific Argumentation Model by Undergraduate Biology Students. Int. J. Sci. Educ. 2019, 41, 2323-2346. [CrossRef]

25. Hsu, W.-C.; Liu, G.-Z. Genre-Based Writing Instruction Blended with an Online Writing Tutorial System for the Development of Academic Writing. Digit. Scholarsh. Humanit. 2019, 34, 100-123. [CrossRef]

26. Lin, C.-C.; Liu, G.-Z.; Wang, T.-I. Development and Usability Test of an E-Learning Tool for Engineering Graduates to Develop Academic Writing in English: A Case Study. Educ. Technol. Soc. 2017, 20, 148-161.

27. Arroyo, R.; Fernández-Lancho, E.; Martínez, E. Digital Competence in Learning Written Academic Argumentation. Ieee Rev. Iberoam. Tecnol. Aprendiz. 2021, 16, 115-121. [CrossRef]

28. Hyland, K. Methods and Methodologies in Second Language Writing Research. System 2016, 59, 116-125. [CrossRef]

29. Swales, J. Coda: Reflections on the Future of Genre and L2 Writing. J. Second Lang. Writ. 2011, 20, 83-85. [CrossRef]

30. Mizumoto, A.; Hamatani, S.; Imao, Y. Applying the Bundle-Move Connection Approach to the Development of an Online Writing Support Tool for Research Articles. Lang. Learn. 2017, 67, 885-921. [CrossRef]

31. Hussin, N.I.S.M.; Nimehchisalem, V. Organisation and Move Structure in the Results and Discussion Chapter in Malaysian Undergraduates' Final-Year Projects. Pertanika J. Soc. Sci. Humanit. 2018, 26, 2365-2377.

32. Arroyo, R.; Jimenez-Baena, A.; Sánchez, E. Eficacia de un curso en PLE, multilingüe, para le enseñanza del ensayo cientifico. Profr. Rev. Currículum Y Form. Profr. 2016, 20, 400-422.

33. Greasley, P.; Cassidy, A. When It Comes Round to Marking Assignments: How to Impress and How to 'Distress' Lecturers ... . Assess. Eval. High. Educ. 2010, 35, 173-189. [CrossRef]

34. O'Hagan, S.R.; Wigglesworth, G. Who's Marking My Essay? The Assessment of Non-Native-Speaker and Native-Speaker Undergraduate Essays in an Australian Higher Education Context. Stud. High. Educ. 2015, 40, 1729-1747. [CrossRef]

35. Luna, M.; Villalón, R.; Mateos, M.; Martín, E. Improving University Argumentative Writing through an Online Training. J. Writ. Res. 2020, 12, 233-262. [CrossRef]

36. Brown, G.T.L.; Marshall, J.C. The Impact of Training Students How to Write Introductions for Academic Essays: An Exploratory, Longitudinal Study. Assess. Eval. High. Educ. 2012, 37, 653-670. [CrossRef]

37. Arroyo, R.; Salvador, F. Research on Cognitive, Social and Cultural Processes of Written Communication. Cogn Process. 2009, 10, 263-268. [CrossRef]

38. Hayes, J. Modeling and Remodeling Writing. Writ. Commun. 2012, 29, 369-388. [CrossRef]

39. Relles, S.R.; Tierney, W.G. Understanding the Writing Habits of Tomorrow's Students: Technology and College Readiness. J. High Educ. 2013, 84, 477-505. [CrossRef]

40. MacArthur, C.A.; Graham, S.; Fitzgerald, J. Handbook of Writing Research, 2nd ed.; Guilford Press: New York, NY, USA, 2017; ISBN 978-1-4625-2931-5.

41. Myhill, D.; Fisher, R. Writing Development: Cognitive, Sociocultural, Linguistic Perspectives. J. Res. Read. 2010, 33, 1-3. [CrossRef]

42. Akyol, Z.; Garrison, D.R. Assessing Metacognition in an Online Community of Inquiry. Internet High. Educ. 2011, 14, 183-190. [CrossRef]

43. Andueza, A. Evaluación de la escritura académica: Construcción y validación de un instrumento integrado basado en tareas para evaluar habilidades específicas de escritura. Relieve 2019, 25, 1-20. [CrossRef]

44. Arroyo, R. Descripción de Procesos En La Composición Escrita de Estudiantes Universitarios Para Un Desarrollo Multilingüe y Tecnológico. Rev. Investig. Educ. 2013, 31, 167-184. [CrossRef]

45. Chen, J.; Zhang, L.J. Assessing Student-Writers' Self-Efficacy Beliefs about Text Revision in EFL Writing. Assess. Writ. 2019, 40, 27-41. [CrossRef]

46. Csizér, K.; Tankó, G. English Majors' Self-Regulatory Control Strategy Use in Academic Writing and Its Relation to L2 Motivation. Appl. Linguist. 2017, 38, 386-404. [CrossRef]

47. Fathi, J.; Ahmadnejad, M.; Yousofi, N. Effects of Blog-Mediated Writing Instruction on L2 Writing Motivation, Self-Efficacy, and Self-Regulation: A Mixed Methods Study. Res. Appl. Linguist. 2019, 10, 159-181. [CrossRef]

48. Karlen, Y. The Development of a New Instrument to Assess Metacognitive Strategy Knowledge about Academic Writing and Its Relation to Self-Regulated Writing and Writing Performance. J. Writ. Res. 2017, 9, 61-86. [CrossRef] 
49. Sasaki, M.; Mizumoto, A.; Murakami, A. Developmental Trajectories in L2 Writing Strategy Use: A Self-Regulation Perspective. Mod. Lang. J. 2018, 102, 292-309. [CrossRef]

50. Limpo, T. Development of a Short Measure of Writing Apprehension: Validity Evidence and Association with Writing Frequency, Process, and Performance. Learn. Instr. 2018, 58, 115-125. [CrossRef]

51. Teng, L.S.; Sun, P.P.; Xu, L. Conceptualizing Writing Self-Efficacy in English as a Foreign Language Contexts: Scale Validation Through Structural Equation Modeling. Tesol Q. 2018, 52, 911-942. [CrossRef]

52. Beach, R.; Newell, G.; VanDerHeide, J. A sociocultural perspective on writing development: Toward am agenda for classroom research on students' use of social practices. In Handbook of Writing Research; Guilford Press: New York, NY, USA, 2017; pp. 88-101.

53. Izquierdo-Magaldi, B.; Renés-Arellano, P.; Gómez-Cash, O. Estrategias metacognitivas y recursos tecnológicos utilizados por estudiantes universitarios de español como segunda lengua. Ocnos Rev. Estud. Sobre Lect. 2016, 15, 149-164. [CrossRef]

54. Bruning, R.H.; Kauffman, D.F. Self-Efficacy Beliefs and Motivation in Writing Development. In Handbook of Writing Research; The Guilford Press: New York, NY, USA, 2017; pp. 160-173.

55. Pajares, F.; Johnson, M.J.; Usher, E.L. Sources of Writing Self-Efficacy Beliefs of Elementary, Middle, and High School Students. Res. Teach. Engl. 2007, 42, 104-120.

56. MacArthur, C.A.; Philippakos, Z.A.; Graham, S. A Multicomponent Measure of Writing Motivation With Basic College Writers. Learn. Disabil. Q. 2016, 39, 31-43. [CrossRef]

57. Bruning, R.; Dempsey, M.; Kauffman, D.; McKim, C.; Zumbrunn, S. Examining Dimensions of Self-Efficacy for Writing. J. Educ. Psychol. 2013, 105, 25-38. [CrossRef]

58. Ramos-Villagrasa, P.J.; Sánchez-Iglesias, I.; Grande-de-Prado, M.; Oliván-Blázquez, B.; Martín-Peña, J.; Cancer-Lizaga, P. Spanish Version of "Self-Efficacy for Writing Scale" (SEWS). Psicol-Spain 2018, 34, 86-102. [CrossRef]

59. Cebrian-Robles, D.; Cebrian-de-la-Serna, M.; Gallego-Arrufat, M.J.; Qintana, J. Impacto de Una Rúbrica Electrónica de Argumentación Científica En La Metodología Blended-Learning. Ried. Rev. Iberoam. Educ. A Distancia 2018, 21, 75-94. [CrossRef]

60. Noroozi, O.; Biemans, H.; Mulder, M. Relations between Scripted Online Peer Feedback Processes and Quality of Written Argumentative Essay. Internet High. Educ. 2016, 31, 20-31. [CrossRef]

61. Cleveland, M.C.; Larkins, E.R. Web-Based Practice and Feedback Improve Tax Students Written Communication Skill. J. Account. Educ. 2004, 22, 211-228. [CrossRef]

62. Van Waes, L.; van Weijen, D.; Leijten, M. Learning to Write in an Online Writing Center: The Effect of Learning Styles on the Writing Process. Comput. Educ. 2014, 73, 60-71. [CrossRef]

63. Cotos, E.; Huffman, S.; Link, S. Understanding Graduate Writers' Interaction with and Impact of the Research Writing Tutor during Revision. J. Writ. Res. 2020, 12, 187-232. [CrossRef]

64. Benetos, K.; Betrancourt, M. Digital Authoring Support for Argumentative Writing: What Does It Change? J. Writ. Res. 2020, 12, 263-290. [CrossRef]

65. Palermo, C.; Wilson, J. Implementing Automated Writing Evaluation in Different Instructional Contexts: A Mixed-Methods Study. J. Writ. Res. 2020, 12, 63-108. [CrossRef]

66. Humphrey, S.; Macnaught, L. Revisiting Joint Construction in the Tertiary Context. Aust. J. Lang. Lit. 2011, 34, 98.

67. Wingate, U. Using Academic Literacies and Genre-Based Models for Academic Writing Instruction: A 'Literacy' Journey. J. Engl. Acad. Purp. 2012, 11, 26-37. [CrossRef]

68. Kuiper, C.; Smit, J.; De Wachter, L.; Elen, J. Scaffolding Tertiary Students' Writing in a Genre-Based Writing Intervention. J. Writ. Res. 2017, 9, 27-59. [CrossRef]

69. Jasrial, D.; Arsyad, S.; Arono, A. The Effect of Genre-Based Mentoring on Linguistic Feature Quality of Research Article Absracts by Indonesian Lecturers in Social Sciences and Humanities. Joall (J. Appl. Linguist. Lit.) 2019, 4, 146-161. [CrossRef]

70. VanDerHeide, J.; Newell, G.E. Instructional Chains as a Method for Examining the Teaching and Learning of Argumentative Writing in Classrooms. Writ. Commun. 2013, 30, 300-329. [CrossRef]

71. Pérez-Llantada, C. Genres in the Forefront, Languages in the Background: The Scope of Genre Analysis in Language-Related Scenarios. J. Engl. Acad. Purp. 2015, 19, 10-21. [CrossRef]

72. Gutiérrez, E.; Trenas, M.A.; Ramos, J.; Corbera, F.; Romero, S. A New Moodle Module Supporting Automatic Verification of VHDL-Based Assignments. Comput. Educ. 2010, 54, 562-577. [CrossRef]

73. Arroyo, R.; Gutierrez-Braojos, C. Competencias escritoras en la formación universitaria del profesorado. Rev. Electrónica Interuniv. Form. Profr. 2016, 19, 135-147. [CrossRef]

74. Meneses, A.L. Competencias Profesionales: El Proceso Escritor y La Calidad Del Ensayo Argumentativo En Universitarios. Tesis Doctoral inédita; Universidad de Granada: Granada, Spain, 2016.

75. Byrne, B. A Primer of LISREL: Basic Applications and Programming for Confirmatory Factor Analytic Models; Springer: New York, NY, USA, 1989.

76. Browne, M.W.; Cudeck, R. Alternative Ways of Assessing Model Fit; Sage: Newbury Park, CA, USA, 1993.

77. Eckstein, G.; Ferris, D. Comparing L1 and L2 Texts and Writers in First-Year Composition. Tesol Q. 2018, 52, 137-162. [CrossRef]

78. Roldán-Nofuentes, J.A.; Regad, S.B. Estimation of the Average Kappa Coefficient of a Binary Diagnostic Test in the Presence of Partial Verification. Mathematics 2021, 9, 1694. [CrossRef] 
79. Lee, J. Can Writing Attitudes and Learning Behavior Overcome Gender Difference in Writing? Evidence From NAEP. Writ. Commun. 2013, 30, 164-193. [CrossRef]

80. Omizo, R.; Hart-Davidson, W. Finding Genre Signals in Academic Writing. J. Writ. Res. 2016, 7, 485-509. [CrossRef]

81. Riehl, C.M. The Interplay of Language Awareness and Bilingual Writing Abilities in Heritage Language Speakers. Languages 2021, 6, 94. [CrossRef]

82. Magnifico, A.M. Writing for Whom? Cognition, Motivation, and a Writer's Audience. Educ. Psychol. 2010, 45, 167-184. [CrossRef]

83. Shea, P.; Bidjerano, T. Learning Presence: Towards a Theory of Self-Efficacy, Self-Regulation, and the Development of a Communities of Inquiry in Online and Blended Learning Environments. Comput. Educ. 2010, 55, 1721-1731. [CrossRef]

84. Canagarajah, S.; Jerskey, M. Meeting the Needs of Advanced Multilingual Writers. In The SAGE Handbook of Writing Development; SAGE Publications Ltd.: Thousand Oaks, CA, USA, 2009; pp. 472-488. ISBN 978-0-85702-106-9.

85. Coronel-Molina, S.M.; Samuelson, B.L. Language Contact and Translingual Literacies. J. Multiling. Multicult. Dev. 2017, 38, 379-389. [CrossRef]

86. Thompson, D.K. Arguing for Experimental "Facts" in Science: A Study of Research Article Results Sections in Biochemistry. Writ. Commun. 1993, 10, 106-128. [CrossRef]

87. Sosa Díaz, M.J.; Guerra Antequera, J.; Cerezo Pizarro, M. Flipped Classroom in the Context of Higher Education: Learning, Satisfaction and Interaction. Educ. Sci. 2021, 11, 416. [CrossRef]

88. Hurtado, I.; Gastañaga, K. Influence of Writing Instruction on Spanish Heritage Learners in Heritage-Only and Mixed Courses: A Longitudinal Study. Languages 2021, 6, 109. [CrossRef]

89. Lucas, C. The Reading and Writing Connections in Developing Overall L2 Literacy: A Case Study. Languages 2020, 5, 69. [CrossRef]

90. Olsen, A.W.; VanDerHeide, J.; Goff, B.; Dunn, M.B. Examining Intertextual Connections in Written Arguments: A Study of Student Writing as Social Participation and Response. Writ. Commun. 2018, 35, 58-88. [CrossRef]

91. Lust, G.; Juarez Collazo, N.A.; Elen, J.; Clarebout, G. Content Management Systems: Enriched Learning Opportunities for All? Comput. Hum. Behav. 2012, 28, 795-808. [CrossRef]

92. Cheng, K.-H.; Tsai, C.-C. An Investigation of Taiwan University Students' Perceptions of Online Academic Help Seeking, and Their Web-Based Learning Self-Efficacy. Internet High. Educ. 2011, 14, 150-157. [CrossRef]

93. Hartshorn, J.; Evans, N. The Effects of Dynamic Written Corrective Feedback: A 30-Week Study. J. Response Writ. $2015,1,2$.

94. Ferris, D.; Eckstein, G. Language Matters: Examining the Language-Related Needs and Wants of Writers in a First-Year University Writing Course. J. Writ. Res. 2020, 12, 321-364. [CrossRef]

95. Qushem, U.B.; Christopoulos, A.; Oyelere, S.S.; Ogata, H.; Laakso, M.-J. Multimodal Technologies in Precision Education: Providing New Opportunities or Adding More Challenges? Educ. Sci. 2021, 11, 338. [CrossRef]

96. Tsai, C.-C.; Cheng, Y.-M.; Tsai, Y.-S.; Lou, S.-J. Impacts of AIOT Implementation Course on the Learning Outcomes of Senior High School Students. Educ. Sci. 2021, 11, 82. [CrossRef]

97. How, M.-L.; Hung, W.L.D. Educing AI-Thinking in Science, Technology, Engineering, Arts, and Mathematics (STEAM) Education. Educ. Sci. 2019, 9, 184. [CrossRef] 